\title{
Survival of eastern oysters Crassostrea virginica from three lines following experimental challenge with bacterial pathogens
}

\author{
Javier Gómez-León ${ }^{1}$, Luisa Villamil ${ }^{1}$, Scott A. Salger ${ }^{1}$, Rachel H. Sallum ${ }^{1}$, \\ Antonio Remacha-Triviño ${ }^{1}$, Dale F. Leavitt ${ }^{2}$, Marta Gómez-Chiarri ${ }^{1,3, *}$ \\ ${ }^{1}$ Department of Fisheries, Animal, and Veterinary Science, University of Rhode Island, Kingston, Rhode Island 02881, USA \\ ${ }^{2}$ Roger Williams University, Bristol, Rhode Island 02809, USA \\ ${ }^{3}$ University of Rhode Island, 23 Woodward Hall, Kingston, Rhode Island 02881, USA
}

\begin{abstract}
Shellfish production is often affected by bacterial pathogens that cause high losses in hatcheries and nurseries. We evaluated the relative survival of larvae and juveniles of 3 Crassostrea virginica oyster lines: (1) GHP, a Rhode Island line; (2) NEHY, a line resistant to dermo and multinucleated sphere X diseases; and (3) FLOWERS, a line resistant to Roseovarius oyster disease, experimental challenge with Vibrio spp. isolates RE22 and RE101, causative agents of bacillary necrosis in Pacific oyster larvae, and the type strain of Roseovarius crassostreae, causative agent of Roseovarius oyster disease. All of the isolates were able to induce significant mortalities in oyster larvae and juveniles. Susceptibility to bacterial challenge in larvae was significantly higher at $25^{\circ} \mathrm{C}$ than at $20^{\circ} \mathrm{C}$. Susceptibility decreased with oyster age; mean survival time ranged from $24 \mathrm{~h}$ in oyster larvae to more than $6 \mathrm{wk}$ in juveniles. Significant differences in susceptibility to bacterial challenge were observed between oyster lines; NEHY was the most resistant line overall. Extracellular products (ECPs) from Vibrio sp. RE22 and R. crassostreae, as well as viable bacteria, were toxic to hemocytes from the 3 oyster lines, suggesting that ECPs are involved in pathogenesis and that external and mucosal barriers to infection are major contributors to resistance to bacterial challenge. These protocols will be useful in the elucidation of mechanisms of bacterial pathogenesis and resistance to infection in oysters.
\end{abstract}

KEY WORDS: Disease resistance $\cdot$ Pathogenesis $\cdot$ Hemocyte viability $\cdot$ Juvenile oyster disease Roseovarius crassostreae $\cdot$ Vibriosis

\section{INTRODUCTION}

The eastern oyster Crassostrea virginica is an important ecological and economical resource of the Gulf of Mexico and Atlantic coasts of North America (Castagna et al. 1996). Several parasitic pathogens, including Perkinsus marinus, causative agent of dermo disease, and Haplosporidium nelsoni, causative agent of multinucleated sphere X (MSX) disease, have seriously hindered culture and restoration efforts of $C$. virginica (Ford \& Tripp 1996). Shellfish production is also often affected by pathogenic bacteria, leading to high mortality rates that occur most frequently during the larval and juvenile stages (Paillard et al. 2004). Mortalities of larval $C$. virginica caused by members of the genus Vibrio were reported in the 1960s and 70s (Tubiash et al. 1965, Elston et al. 1980, Brown 1981, Brown \& Tettelbach 1988). Another bacterial species, Roseovarius crassostreae, has been recently described as the causative agent of juvenile oyster disease (JOD) (Boettcher et al. 2005), and the disease is now referred to as Roseovarius oyster disease (ROD) (Maloy et al. 2007). ROD causes losses that may exceed $90 \%$ of total production at enzootic sites in the northeastern USA (Boettcher et al. 2006). Gross signs of the disease include organic deposits in the inner valves of the oys- 
ter that form a light to dark brown ring typically located inside the valve margins (Bricelj et al. 1992, Ford \& Borrero 2001). The impact of ROD may vary from year to year; individuals $<25 \mathrm{~mm}$ in shell height appear to be especially vulnerable when seawater temperatures exceed $25^{\circ} \mathrm{C}$ (Bricelj et al. 1992, Davis \& Barber 1994, Boettcher et al. 1999). Oysters with gross signs consistent with ROD have also been reported from C. virginica reared in France (Renault et al. 2002), indicating that this problem may be more pervasive than originally thought, and is not restricted to the northeastern USA.

One of the most efficient management strategies for the prevention of infectious diseases in bivalves is the development of disease-resistant lines through selective breeding (Roch 1999). Several efforts have been made to obtain lines of Crassostrea virginica resistant to MSX, dermo, and ROD through selective breeding. Both natural epizootics and controlled selection and breeding experiments at Rutgers University and the Virginia Institute of Marine Science have produced lines of oysters with increased resistance to MSX disease-related mortality. These lines are currently being further developed to impart resistance to dermo disease as well (Ragone Calvo et al. 2003, Yu \& Guo 2006). At least 2 lines with resistance to ROD are currently available: the FLOWERS line, developed by the Frank M. Flowers Company from survivors of natural ROD outbreaks (Lewis 2001); and the University of Maine Flowers Select line, originated in 1986 by crossing FLOWERS with wild Damariscotta stocks, and selected for faster growth in cooler Maine waters (Barber et al. 1998, Davis \& Barber 1999).

In order to gain a better understanding of the pathogenesis of bacterial diseases in eastern oysters, as well as to evaluate mechanisms of disease resistance, we developed tools to experimentally challenge oysters with bacterial pathogens and used those tools to compare the relative survival of several oyster lines to bacterial challenge. Oyster larvae and juveniles from 3 lines were experimentally challenged with 2 bacterial isolates (Vibrio spp. RE22 and RE101) known to cause mortalities in Pacific oyster larvae (Estes et al. 2004) and the causative agent of ROD, Roseovarius crassostreae (strain CV919-312 ${ }^{\mathrm{T}}$ ) (Boettcher et al. 2005). The post-exposure survivals and histological lesions caused by challenge with these 3 bacterial isolates are described, as well as the effects of their extracellular products on the survival of oyster hemocytes in vitro.

\section{MATERIALS AND METHODS}

Oysters. Three Crassostreae virginica lines were used in all experiments unless otherwise specified: (1) a line derived from wild broodstock collected from an area with known moderate to heavy exposure to dermo and MSX diseases and located in Green Hill Pond, Rhode Island (GHP); (2) a dermo and MSX diseases-resistant line, Rutgers NEHY (Yu \& Guo 2006); and (3) a ROD-resistant line, FLOWERS (Lewis 2001). Broodstock oysters from the NEHY line were provided by G. DeBrosse (Haskin Shellfish Research Laboratory). FLOWERS broodstock and juveniles were purchased from Frank M. Flowers Company. Broodstock oysters were transported to the Roger Williams University (RWU) hatchery and spawned using standard hatchery protocols. Oysters were kept in common conditions at the RWU hatchery and nursery upwellers for at least 1 mo prior to transportation to the Aquatic Pathology Laboratory at the University of Rhode Island for experimental challenges. Oysters were maintained in 501 aquaria in artificial sea water at a salinity of 28 to $30 \%$ and a temperature of 20 to $22^{\circ} \mathrm{C}$ with aeration, and fed with an algal mixture of Tetraselmis sp., Pavlova sp., Thallassiosa sp., and Isochrysis sp. (Instant Algae, Reed Mariculture). The water was partially changed (50\%) twice weekly.

Bacterial isolates. Vibrio spp. isolates RE22 and RE101 were provided by R. Elston (AquaTechnics) and cultured on trypic soy agar with $1 \%$ (w/v) of supplemental $\mathrm{NaCl}$ (TSAS). The isolate $\mathrm{CV} 919-312^{\mathrm{T}}$ of Roseovarius crassostreae, donated by $\mathrm{K}$. Boettcher (University of Maine) was cultured on seawater tryptone agar (SWT) (Boettcher et al. 1999). For the experimental challenges, bacterial isolates were grown for 24 to $36 \mathrm{~h}$ at room temperature on their respective solid media. After that time, bacteria were removed from plates with sterile swabs and suspended in $1 \mathrm{ml}$ sterile sea water (SSW). Bacterial concentrations were adjusted by direct counting in the microscope PetroffHauser counting chamber (Hauser Scientific). Bacterial concentrations were confirmed by enumeration on respective solid media using conventional dilution platting with incubation at room temperature for $2 \mathrm{~d}$ (Gomez-Leon et al. 2005). For long-term preservation, isolates CV919-312 ${ }^{\mathrm{T}}, \mathrm{RE} 22$, and RE101 were frozen at $-80^{\circ} \mathrm{C}$ in SWT or tryptic soy broth (TSB) supplemented with $1 \%(\mathrm{w} / \mathrm{v})$ of $\mathrm{NaCl}_{\text {; }}$ both preservation media contained $25 \%$ (v/v) glycerol.

Experimental challenges. Pathogenicity assays in larvae were carried out in sterile 24 -well culture plates (BD Falcon) following a modification of the protocol described by Estes et al. (2004). Briefly, 10 to 12 larvae ( 8 to $12 \mathrm{~d}$ old,$<1 \mathrm{~mm}$ ) were placed in each well containing $1 \mathrm{ml}$ of SSW at 28 to 30\%. Oyster larvae were challenged by bath with Vibrio spp. isolates RE22 and RE101, and Roseovarius crassostreae CV919-312 ${ }^{\mathrm{T}}$ at a final concentration in the bath water of $5 \times 10^{5}$ colony forming units (CFU) $\mathrm{ml}^{-1}$; control larvae without bacte- 
ria were also included. Each experimental group was done in triplicate. Plates were incubated for $48 \mathrm{~h}$ at 20 or $25^{\circ} \mathrm{C}$. Survival was determined by direct observation using an inverted microscope (Leica Dmil, Leica Microsystems) using the following criteria: (1) live larvae include swimming larvae and larvae with valves closed but showing internal movement, and (2) dead larvae include closed larvae without internal movement. In the case of the juveniles, groups of 50 oysters ranging from 4 to $6 \mathrm{~mm}$ in shell height for the FLOWERS line and from 5 to $9 \mathrm{~mm}$ for the GHP and NEHY lines were placed in circular flat-bottom $100 \mathrm{ml}$ containers. Larger oyster sizes ranging from 15 to $22 \mathrm{~mm}$ in shell height from the 3 lines were placed in 11 containers. Triplicate groups of oysters were experimentally challenged by bath with either Vibrio sp. RE22 or R. crassostreae CV919-312 ${ }^{\mathrm{T}}$ at a final concentration in the bath water of $5 \times 10^{5} \mathrm{CFU} \mathrm{ml}^{-1}$. Control containers without bacteria inoculation were also included. Oysters were maintained in SSW at 28 to $30 \%$ at $25^{\circ} \mathrm{C}$ with partial aeration $\left(12 \mathrm{~h} \mathrm{~d}^{-1}\right)$, and fed with Instant Algae (Reed Mariculture). The water was partially changed (50\%) weekly. Survival rates were determined weekly counting dead and live oysters in each container. Size (shell heights in $\mathrm{mm}$ ) of the oysters were also determined. Results were expressed as mean percent survival + SD. Recently dead and moribund oysters were sampled to re-isolate and identify associated bacteria. In all cases, mortalities were attributed to the inoculated bacterial strain if it was the predominant bacterial species recovered from gaping or dead challenged oysters.

Condition index. Thirty oysters from each line with sizes ranging from 15 to $22 \mathrm{~mm}$ in shell height were processed for determination of the condition index following the method of Abbe \& Albright (2003).

Histopathological examination. Selected samples of oysters from the experimental challenges were fixed in Davidson's fixative (Shaw \& Battle 1957) for 24 h. Tissue samples were processed in an automatic tissue processor, embedded in paraffin wax blocks, and cut on a microtome. Sections of $5 \mu \mathrm{m}$ were deparaffinized, rehydratated, and stained with hematoxylin and eosin (H\&E). Histopathological examinations of all samples were performed with a light microscope (Nikon Eclipse E-600) and a SPOT Insight 2 digital camera with SPOT software, v4.6 (Diagnostic Instruments).

Detection of Roseovarius crassostreae in oyster tissues by immunofluorescence. Histological sections mounted on Superfrost Plus slides (Fisher Scientific) were deparaffinized, rehydrated through ethanol graded series, equilibrated in phosphate buffered saline (PBS), and incubated for $1 \mathrm{~h}$ at room temperature in blocking buffer (BlockHen, Avies Labs). Slides were washed in washing buffer (PBS with $0.05 \%$ [v/v]
Tween-20 [PBST]) and incubated in a humid chamber at room temperature for $1 \mathrm{~h}$ with a 1:250 dilution in PBS of a chicken anti-Roseovarius crassostreae (CV919-312 ${ }^{\mathrm{T}}$ ) polyclonal antibody (Boardman 2005). Slides were washed in PBST, incubated for $1 \mathrm{~h}$ at room temperature with a 1:200 dilution of goat anti-chicken antibody labeled with Alexa Fluor 546 (Molecular Probes), washed, and cover slipped using Prolong Gold (Molecular Probes) antifade and mounting medium. Negative controls were performed by omitting either the primary antibody, the secondary antibody, or substituting the primary antibody with preimmune serum. Sections were examined using a Zeiss AxioPlan 2 epifluorescent microscope with a Zeiss AxioCam digital camera and Zeiss AxioVision v4.5 imaging software (Carl Zeiss).

Preparation of bacterial extracellular products (ECPs). Bacterial ECPs from Vibrio sp. RE22 and Roseovarius crassostreae CV919-312 ${ }^{\mathrm{T}}$ were obtained using the cellophane plate technique (Liu 1957), by spreading $0.1 \mathrm{ml}$ of a $24 \mathrm{~h}$ broth culture over sterilized cellophane sheets placed on TSAS. Plates were incubated for $24 \mathrm{~h}$ at room temperature and the cells washed of the cellophane with phosphate buffered saline. Suspensions were centrifuged at $10000 \times g$ for $30 \mathrm{~min}$ at $4^{\circ} \mathrm{C}$, and supernatants were filtered through $0.45 \mu \mathrm{m}$ membranes and stored at $-80^{\circ} \mathrm{C}$ until required. The protein concentration of the ECPs was evaluated with Coomasie Brilliant Blue assays (Bio Rad Laboratories).

Hemolymph extraction and effect of bacteria on hemocyte viability. Adult oysters from the 3 oyster lines were maintained separately in 501 tanks of aerated artificial seawater at $15^{\circ} \mathrm{C}$ and $28 \%$ of salinity and fed daily with Instant Algae. Oyster shells were notched and $1 \mathrm{ml}$ of hemolymph was withdrawn from each oyster by the adductor muscle sinus with a disposable syringe. The number of viable hemocytes in each oyster's hemolymph was counted with a hemacytometer after staining with trypan blue. Since the concentration of hemocytes in each oyster was similar (around $1 \times 10^{6}$ hemocytes $\mathrm{ml}^{-1}$ of hemolymph), hemocytes were left in the hemolymph to avoid further cell manipulation. Hemolymphs extracted from 10 oysters were pooled; 3 pools of 10 oysters each were used for each treatment. Treatments included viable or heatkilled $\left(100^{\circ} \mathrm{C}, 2 \mathrm{~h}\right)$ bacteria at doses of $10,10^{3}$, and $10^{6}$ $\mathrm{CFU} \mathrm{ml}{ }^{-1}$, and heat-treated $\left(100^{\circ} \mathrm{C}, 2 \mathrm{~h}\right)$ or non-treated bacterial ECPs at 75, 150, and $300 \mu \mathrm{g} \mathrm{ml}^{-1}$. After 4 and $24 \mathrm{~h}$ of incubation with the different treatments, respectively, aliquots were taken and cell viabilities determined by trypan blue exclusion assays with 3 replicate counts per sample. Data were expressed as percent cell viability. The effect of treatments on cell morphologies was determined by observation with an inverted microscope. 
Statistics. Differences in hemocyte viabilities between oyster lines were tested by 2-way ANOVA using Sigmastat 3.1 software (Systat). Data collected as percentages were transformed (arcsine of the square root) before analysis. Differences in survival between oyster lines were tested with the Kaplan-Meier log-rank (nonparametric test) survival analysis using SigmaStat 3.1. Multiple comparisons were done using the HolmSidak post-hoc method. Results were deemed significant at $\mathrm{p}<0.05$.

\section{RESULTS}

\section{Experimental challenges}

\section{Larvae}

Experimental challenges by bath exposure showed that Vibrio spp. isolates RE22 and RE101, and Roseovarius crassostreae CV919-312 ${ }^{\mathrm{T}}$ induced significant mortalities in larvae of Crassostrea virginica after $24 \mathrm{~h}$ of exposure at either 20 or $25^{\circ} \mathrm{C}$ (Fig. 1). Low or absent larval mortalities were observed in unchallenged control larvae. Significantly higher mortalities of GHP larvae were observed at $25^{\circ} \mathrm{C}$ than at $20^{\circ} \mathrm{C}$ when exposed to Vibrio sp. isolate RE101 and R. crassostreae CV919$312^{\mathrm{T}}$. Significant differences between oyster lines in percent survival to challenge with Vibrio sp. RE101 were observed at $20^{\circ} \mathrm{C}$ (mean survival time \pm SD: $37 \pm$ $3 \mathrm{~h}$ for GHP, $43 \pm 1 \mathrm{~h}$ for NEHY, $\mathrm{p}<0.001$ ), as well as to challenge with $R$. crassostreae CV919-312 ${ }^{\mathrm{T}}(27 \pm 2 \mathrm{~h}$ for GHP, $38 \pm 2 \mathrm{~h}$ for NEHY, $\mathrm{p}<0.001$ ), but not with the highly pathogenic Vibrio sp. isolate RE22 $(24 \pm 1 \mathrm{~h}$ for all oyster lines). Vibrio sp. isolate RE22 was significantly more pathogenic to NEHY oysters than isolate RE101 and R. crassostreae CV919-312 ${ }^{\mathrm{T}}$. No statistical differences in survival were observed between oyster lines, or between bacterial isolates, at $25^{\circ} \mathrm{C}$, probably due to the severity of the challenge (Fig. 1b).

Microscopic examination of larvae from the GHP and NEHY lines at regular intervals during experimental challenges showed that the first sign of disease was a reduction of motility, followed by an abnormal circular pattern of swimming, and, finally, the inability to swim. The abnormal velum of these moribund larvae was stalk-like with clumped cilia (Fig. 2b). At the peak of mortalities, bacteria swarming inside and around dead and moribund larvae were observed (not shown). No lesions or abnormal swimming were observed in non-infected control individuals (Fig. 2a). Histopathological examination revealed the presence of rodshaped bacteria and phagocytic cells in the visceral cavity of larva infected with Vibrio spp. RE22 (Fig. 2c,d) and RE101. No lesions were observed in

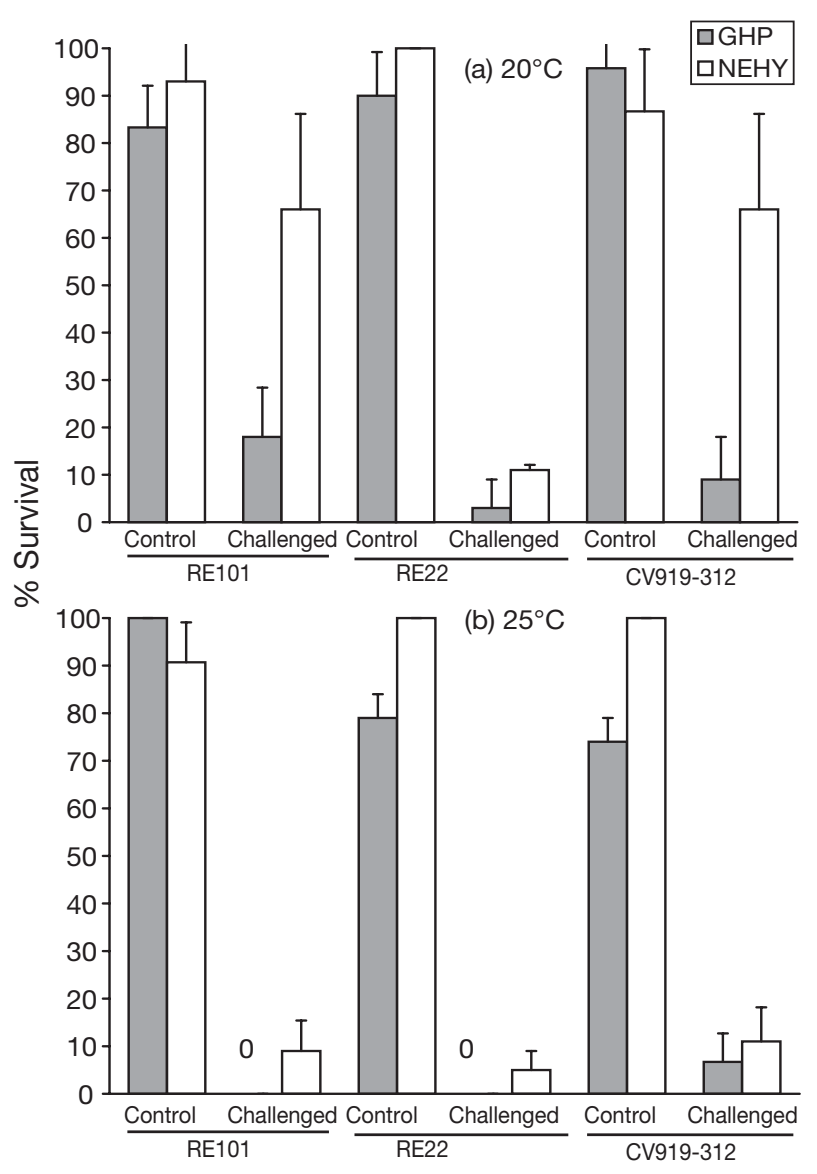

Fig. 1. Crassostrea virginica. Percent survival of oyster larvae challenged by bath in $5 \times 10^{5} \mathrm{CFU} \mathrm{ml}^{-1}$ of Vibrio spp. isolates RE101 and RE22, and Roseovarius crassostreae CV919-312 for $24 \mathrm{~h}$ at (a) $20^{\circ} \mathrm{C}$ and (b) $25^{\circ} \mathrm{C}$. Data are expressed as mean $+\mathrm{SD}$ of \% of oyster survival of 3 replicate groups of 10 to 12 larvae per treatment. For treatments without mortalities, mortality bars are located by zeros

larvae infected with $R$. crassostreae CV919-312 ${ }^{\mathrm{T}}$ or non-infected control larvae (not shown).

\section{Juvenile oysters}

No significant differences were observed between the condition indices of the 3 oyster lines (not shown). Experimental challenge of oyster juveniles (4-9 mm shell height) with Vibrio sp. RE22 and Roseovarius crassostreae CV919-312 ${ }^{\mathrm{T}}$ at $25^{\circ} \mathrm{C}$ resulted in mortalities in the 3 oyster lines. Significant differences in survival were detected; FLOWERS was the least resistant line since no surviving individuals remained $27 \mathrm{~d}$ postchallenge (Fig. 3). According to the survival analysis, NEHY was significantly more resistant than GHP and FLOWERS to challenge with $R$. crassostreae CV919$312^{\mathrm{T}}$, with a mean survival time of $28 \pm 1 \mathrm{~d}$ compared to 

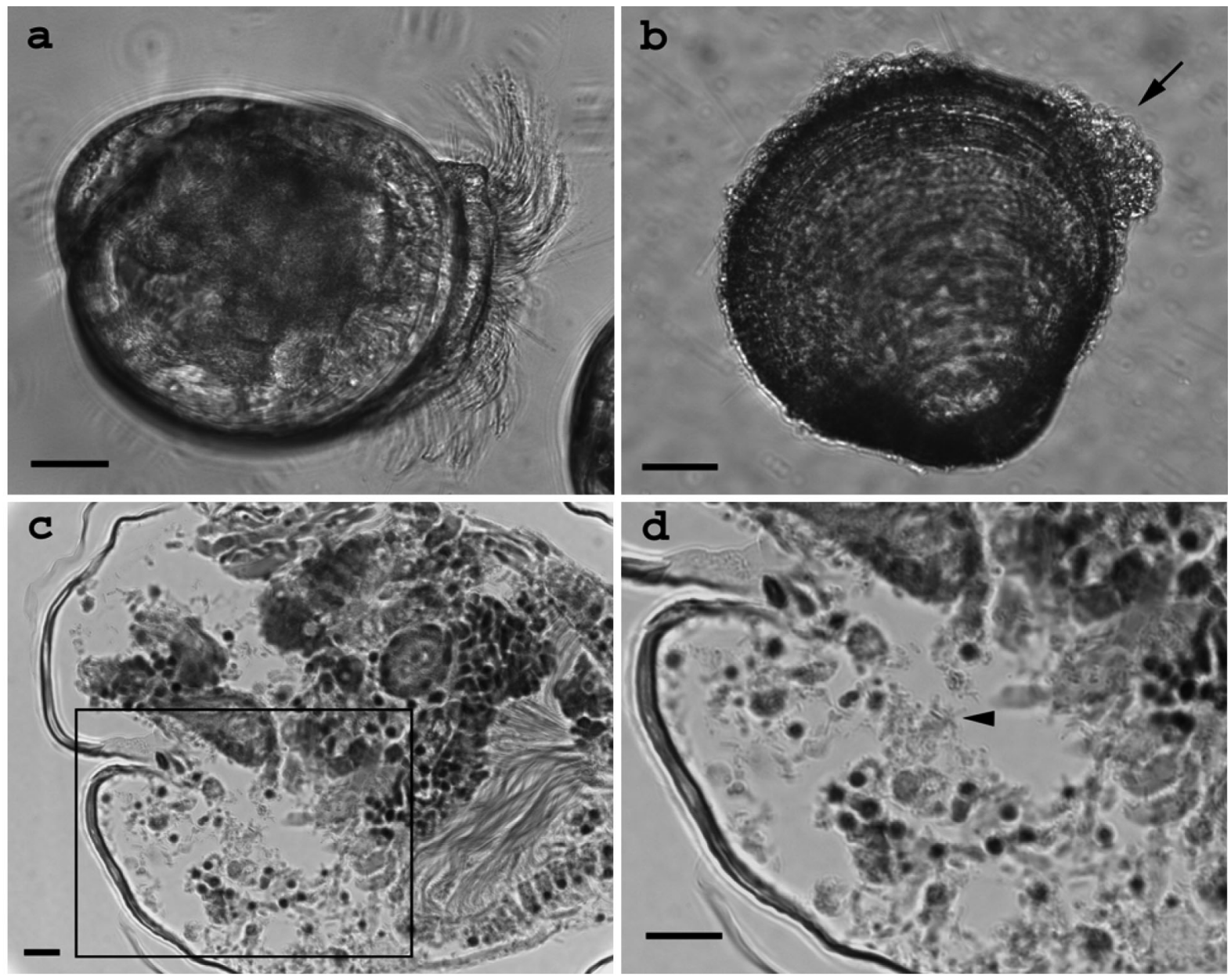

Fig. 2. Crassostrea virginica. Larvae experimentally challenged for $24 \mathrm{~h}$ with Vibrio spp. isolates RE22 and RE101, or Roseovarius crassostreae CV919-312 ${ }^{\mathrm{T}}$. (a) Unchallenged larva; (b) challenged larva showed deformed vela with clumped cilia (arrow); (c \& d) H\&E-stained histological section of larva challenged with Vibrio sp. RE22 showed rod-shaped bacteria (arrowhead) and phagocytic cells in the visceral cavity, (d) is a higher magnification of the area boxed in (c). Scale bars $=10 \mu \mathrm{m}$

$9 \pm 1 \mathrm{~d}$ for both FLOWERS and GHP ( $\mathrm{p}<0.001)$. In the case of challenges with Vibrio sp. RE22, survival for all lines was significantly different ( $<<0.05)$, with NEHY oysters showing the highest mean survival time $(24 \pm$ $1 \mathrm{~d})$, then GHP $(15 \pm 1 \mathrm{~d})$, and FLOWERS (10 \pm 1 d) oysters. For a particular line, no significant differences in survival to experimental challenge with isolates RE22 or CV919-312 ${ }^{\mathrm{T}}$ were observed, with the exception of the GHP line, which was more resistant to Vibrio sp. RE22 than to $R$. crassostreae CV919-312 ${ }^{\mathrm{T}}$. Although low levels of mortality occurred in unchallenged oysters, neither Vibrio sp. RE22 nor $R$. crassostreae CV919-312 ${ }^{\mathrm{T}}$ were isolated from these oysters. No significant relationship between oyster size and time to mortality was observed in infected oysters in this size range $\left(\mathrm{r}^{2}=0.002, F=0.422\right)$.

In the case of larger juvenile oysters (15-22 mm shell height), a longer time was required to induce mortali- ties after experimental challenge with Vibrio sp. RE22 and Roseovarius crassostreae CV919-312 ${ }^{\mathrm{T}}$ at $25^{\circ} \mathrm{C}$ than in smaller juveniles (Fig. 4). No significant differences in survival after bacterial challenge with Vibrio sp. RE22 or $R$. crassostreae CV919-312 ${ }^{\mathrm{T}}$ were observed between the 3 oyster lines. Following challenges with Vibrio sp. RE22, mean survival time ranged from $8.2 \pm$ $0.5 \mathrm{wk}$ for GHP oysters to $9.3 \pm 0.3 \mathrm{wk}$ for both NEHY and FLOWERS oyster lines. Following challenges with R. crassostreae CV919-312 ${ }^{\mathrm{T}}$, mean survival time was $7.8 \pm 0.6$ wk for FLOWERS, $9.3 \pm 0.4$ for NEHY, and $9.7 \pm 0.3 \mathrm{wk}$ for GHP oysters.

Oyster juveniles experimentally challenged with Vibrio sp. RE22 presented histological lesions characterized by disorganization of muscle fibers, hemocytic infiltration, and necrosis in the mantle (not shown). In the case of oyster juveniles infected with Roseovarius crassostreae CV919-312 ${ }^{\mathrm{T}}$, lesions were characterized 

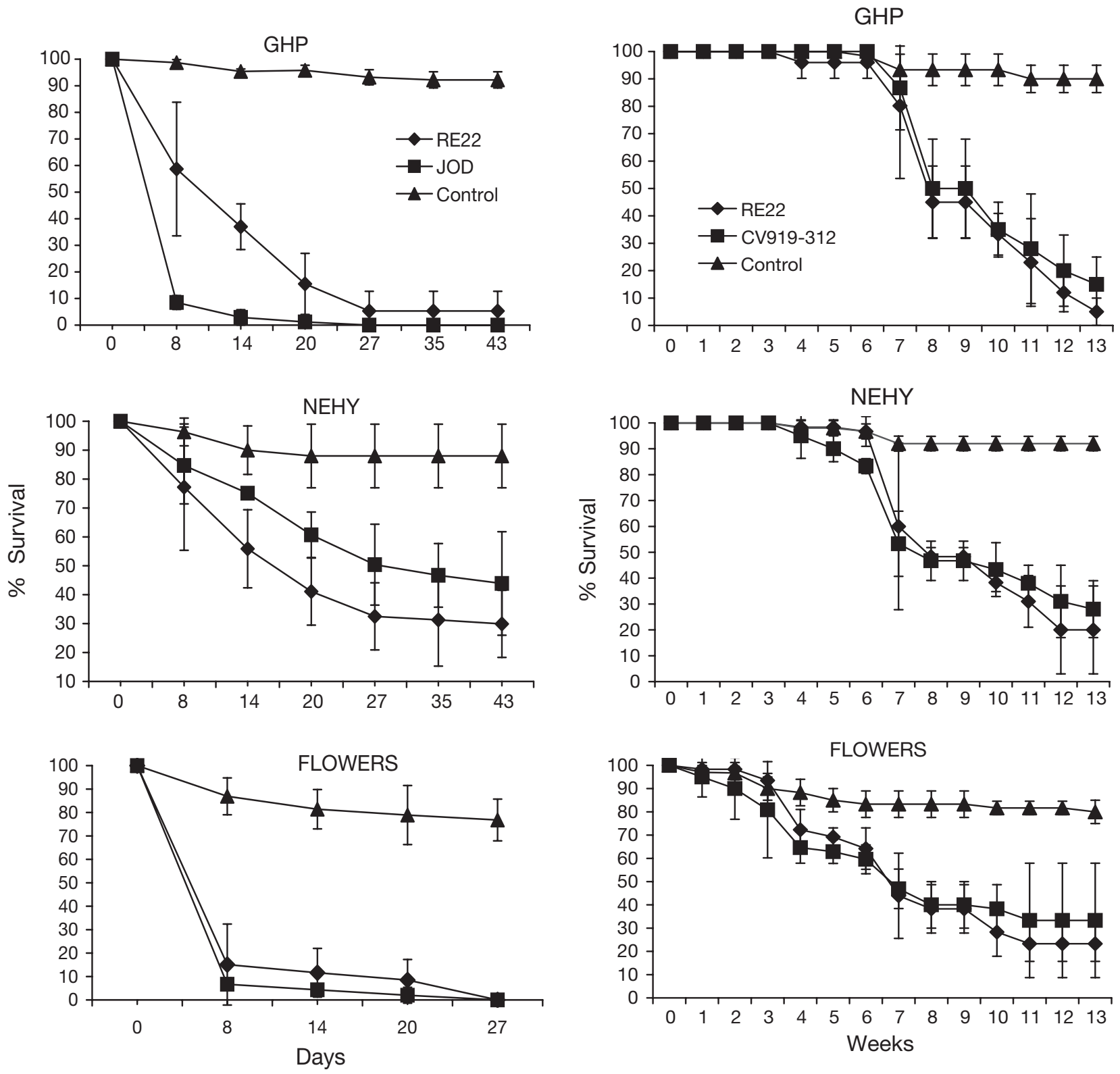

Fig. 3. Crassostrea virginica. Percent survival of oyster juveniles (4-9 mm shell height) from 3 lines experimentally challenged by bath in $5 \times 10^{5} \mathrm{CFU} \mathrm{ml}^{-1}$ of Vibrio sp. RE22 or Roseovarius crassostreae CV919-312 ${ }^{\mathrm{T}}$ for $43 \mathrm{~d}$ at $25^{\circ} \mathrm{C}$. Data expressed as mean $\pm \mathrm{SD}$ of $\%$ oyster survival of 3 replicate groups of 50 oysters per line and treatment

by degeneration and erosion of the mantle associated with hemocytic infiltration and the presence of organic deposits (conchiolin), as well as the presence of dense spherical bodies in the mantle (Fig. 5a,b). No histological lesions were observed in unchallenged control oysters (not shown). Immunofluorescent labeling of histological sections from juvenile oysters challenged with $R$. crassostreae CV919-312 ${ }^{\mathrm{T}}$ with an anti-R. crassostreae antibody showed the presence of rod-shaped

Fig. 4. Crassostrea virginica. Percent survival of oyster juveniles (15-22 mm shell height) from the 3 lines experimentally challenged by bath in $5 \times 10^{5} \mathrm{CFU} \mathrm{ml}^{-1}$ of Vibrio sp. RE22 or Roseovarius crassostreae CV919-312 ${ }^{\mathrm{T}}$ for $14 \mathrm{wk}$ at $25^{\circ} \mathrm{C}$. Data expressed as mean \pm SD of \% oyster survival of 3 replicate groups of 50 oysters per line and treatment

bacteria on the surface of the mantle and within the conchiolin (Fig. 5c,d), but not within oyster tissues, nor in unchallenged oysters. Macroscopically, oysters (15-22 mm shell height) challenged with $R$. crassostreae CV919-312 ${ }^{\mathrm{T}}$ showed conchiolin deposits on interior valve surfaces 3 to 4 wk post-challenge, while no gross signs of ROD were observed in oyster juveniles less than $15 \mathrm{~mm}$ shell height or in control oysters (not shown). 

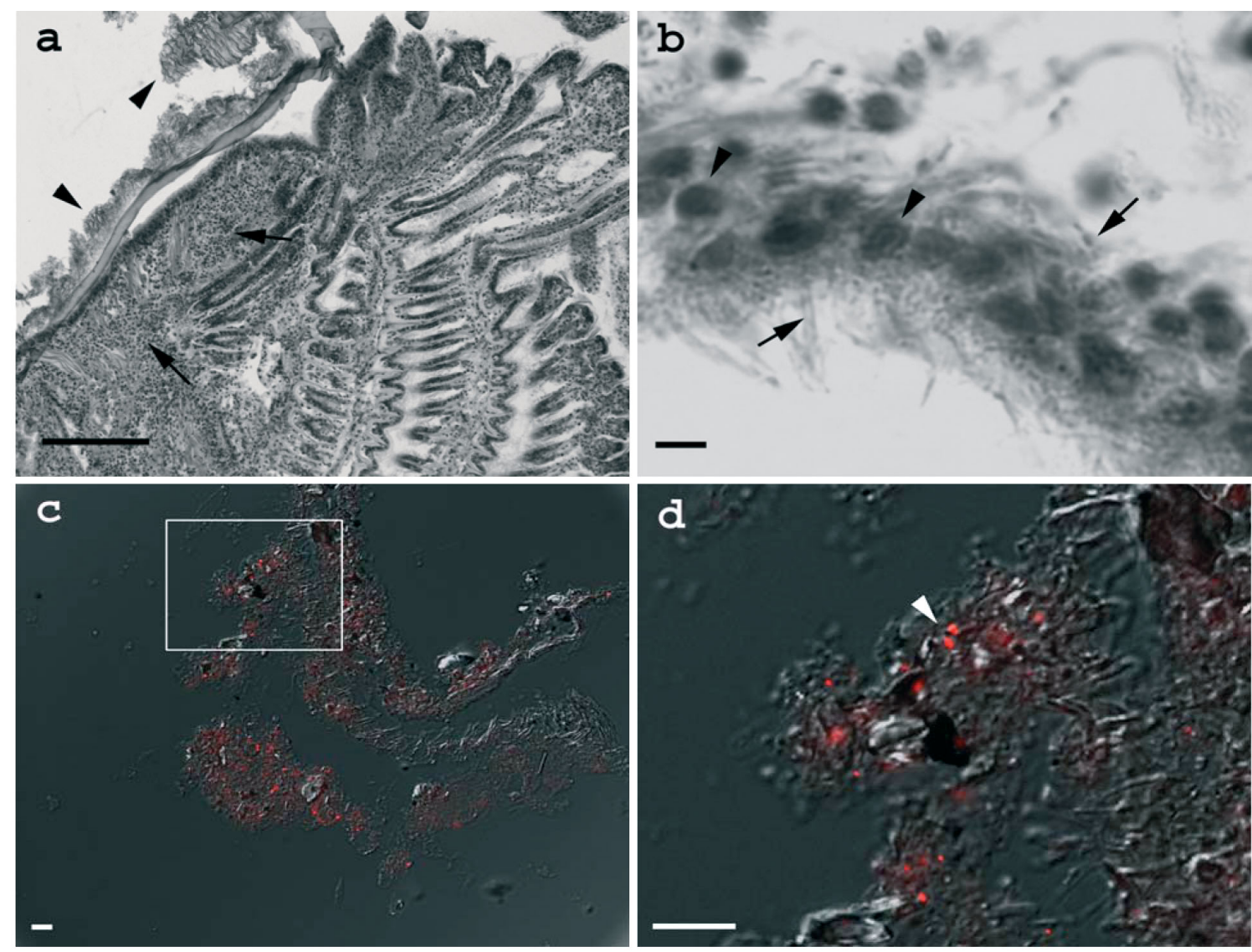

Fig. 5. Crassostrea virginica. Representative photomicrographs of oyster juveniles experimentally challenged with Roseovarius crassostreae CV919-312 ${ }^{\mathrm{T}}$. H\&E-stained sections of a challenged oyster showing: (a) degeneration and erosion of the mantle associated with hemocytic infiltration (arrows) and the presence of conchiolin (arrowheads) (scale bar $=100 \mu \mathrm{m}$ ); (b) bacteria (arrows) and dense spherical bodies (arrowhead) in the mantle (scale bar $=5 \mu \mathrm{m}$ ); (c \& d) immunofluorescent labeling of $R$. crassostreae in histological sections of a challenged oyster showing the presence of rod-shaped labeled bacteria (arrowhead) within conchiolin deposits, (d) is a magnification of the area boxed in (c) (scale bars $=10 \mu \mathrm{m})$

\section{Effect of bacteria on oyster hemocyte viability}

The viabilities of hemocytes from oysters of the GHP, NEHY, and FLOWERS lines were significantly reduced after $4 \mathrm{~h}$ (data not shown) and $24 \mathrm{~h}$ of incubation with viable bacterial cells $\left(10,10^{3}\right.$, and $\left.10^{6} \mathrm{CFU} \mathrm{ml}^{-1}\right)$ of Vibrio sp. RE22 or Roseovarius crassostreae CV919$312^{\mathrm{T}}$ (Fig. 6). Significantly lower survival to bacterial challenge $\left(10^{3}\right.$ and $10^{6} \mathrm{CFU} \mathrm{ml}{ }^{-1}$ of isolates RE22 or CV919-312 ${ }^{\mathrm{T}}$ ) occurred among hemocytes from GHP in comparison to hemocytes from FLOWERS and NEHY oysters $(p<0.05)$. For hemocytes from each oyster line, viabilities were inversely proportional in nominal dose responses to challenge concentrations of live bacterial cells. No significant differences were observed between survivals of unchallenged control hemocytes and hemocytes challenged with heat-killed bacteria.

Incubation of hemocytes with ECPs from Vibrio sp. RE22 and Roseovarius crassostreae CV919-312 ${ }^{\mathrm{T}}$ signif- icantly reduced their survival relative to unchallenged hemocytes (Fig. 7). No significant differences between oyster lines were detected in the effect of bacterial ECPs on hemocyte survival. For hemocytes from each oyster line, viabilities were inversely proportional in nominal dose responses to concentrations of nonheated bacterial ECPs. The toxic effects of all the ECPs on hemocytes were eliminated when ECPs were heattreated.

Differences in hemocyte morphologies were observed following incubation with viable Vibrio sp. RE22 bacteria, as well as with non-heated ECPs. These changes were characterized by a high proportion of rounded refringent hemocytes (Fig. 8b) that were not observed in untreated cells (Fig. 8a). Similar results were observed following incubation of oyster hemocytes to live bacteria and non-heated ECPs from Roseovarius crassostreae CV919-312 ${ }^{\mathrm{T}}$ (not shown). 


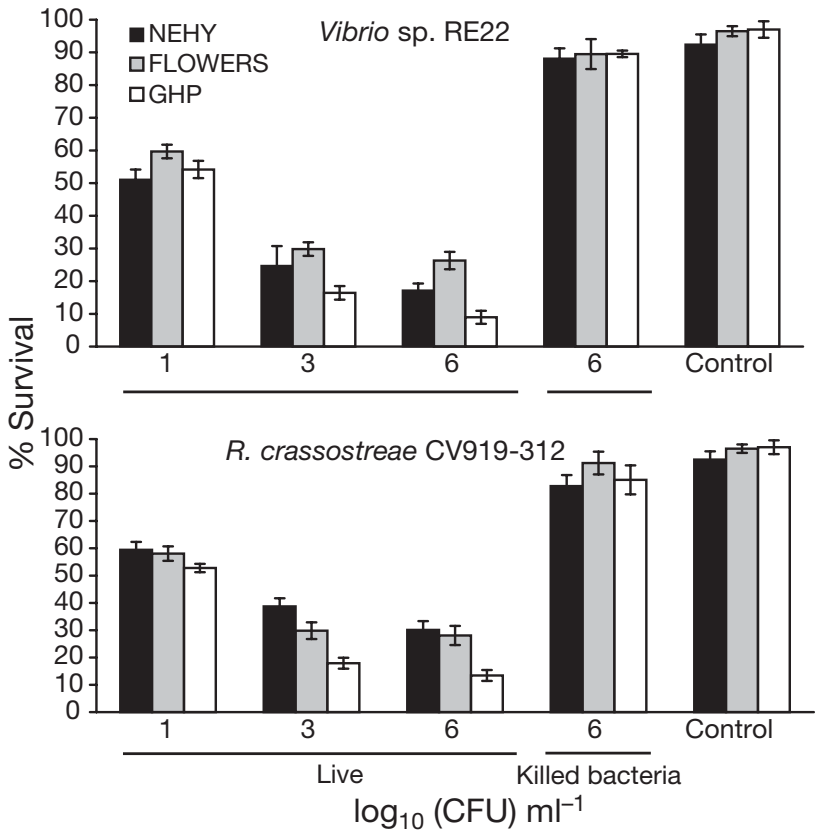

Fig. 6. Crassostrea virginica. Viabilities of oyster hemocytes incubated for $24 \mathrm{~h}$ at $20^{\circ} \mathrm{C}$ with viable and heat-killed Vibrio sp. RE22 and Roseovarius crassostreae CV919-312 ${ }^{\mathrm{T}}$ cells at concentrations of $10,10^{3}$, and $10^{6} \mathrm{CFU} \mathrm{ml}^{-1}$. Data expressed as mean $\pm \mathrm{SD}$ of \% viable hemocytes in 3 hemolymph pools per experimental group. The experiment was performed twice

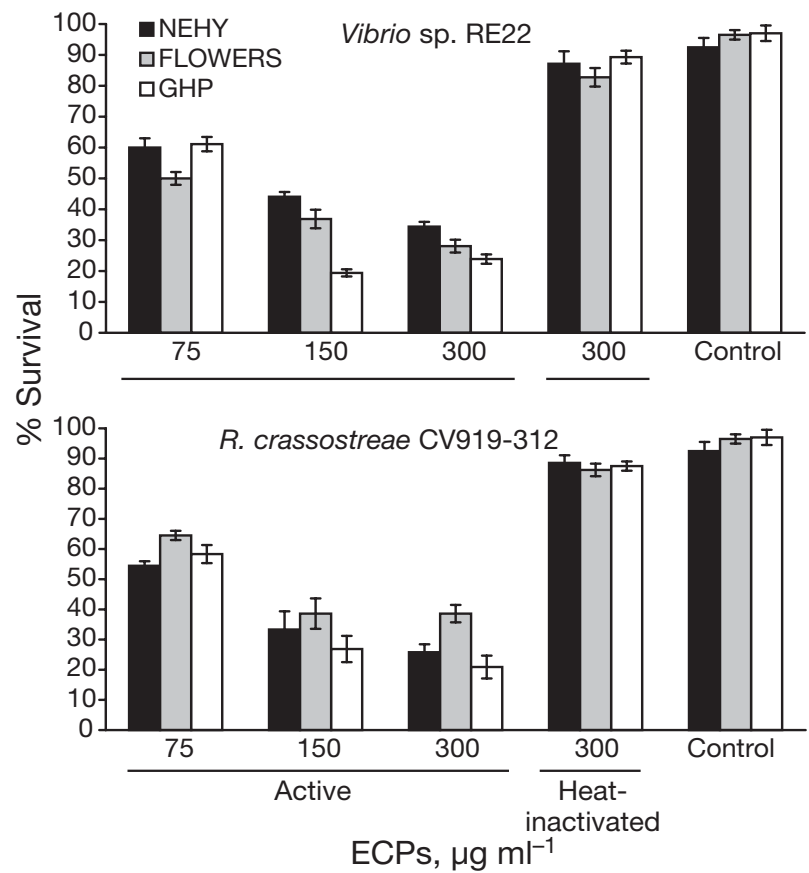

Fig. 7. Crassostrea virginica. Viability of oyster hemocytes incubated for $24 \mathrm{~h}$ at $20^{\circ} \mathrm{C}$ with ECPs of Vibrio sp. RE22 and Roseovarius crassostreae CV919-312T at concentrations of 75, 150 , and $300 \mu \mathrm{g} \mathrm{ml}^{-1}$. Data expressed as mean $\pm \mathrm{SD}$ of $\%$ viable hemocytes in 3 hemolymph pools per experimental group. The experiment was performed twice
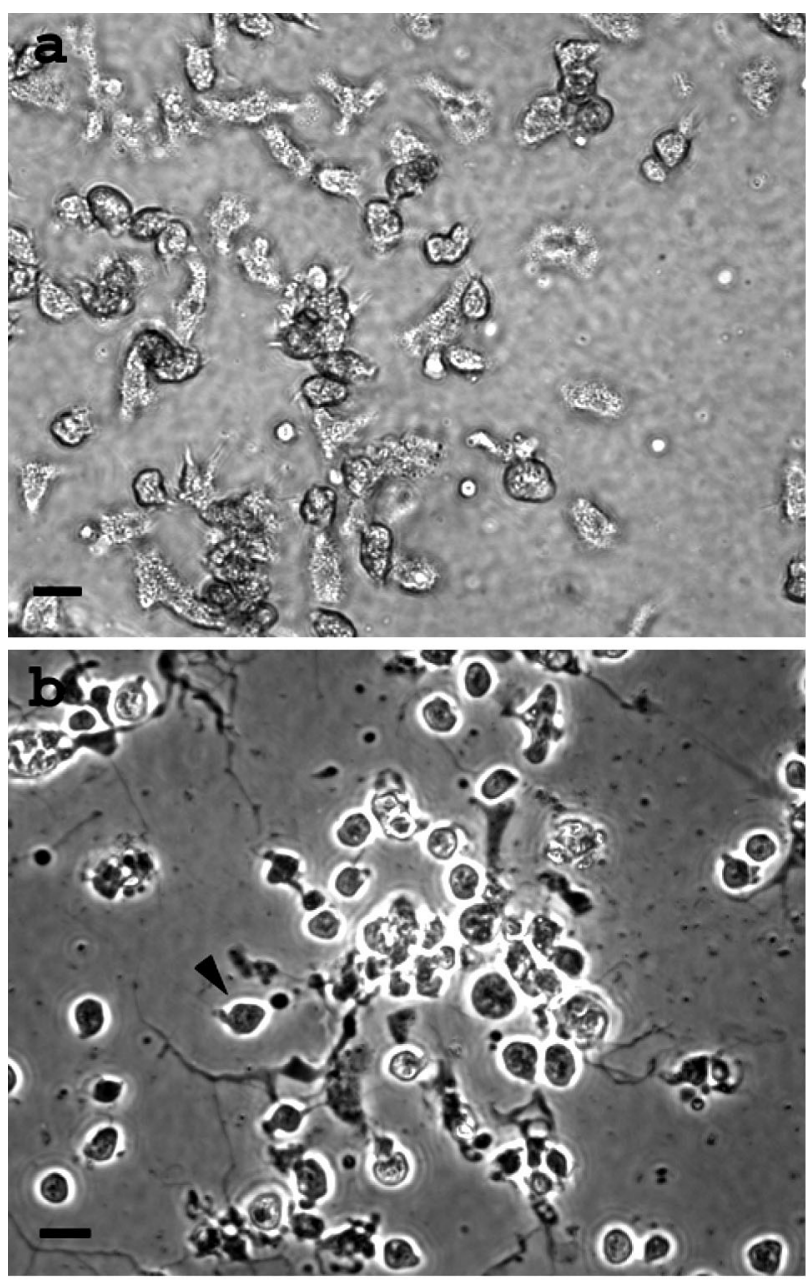

Fig. 8. Crassostrea virginica. Representative phase-contrast photomicrographs showing the effect of bacteria on hemocytes of oysters from the FLOWERS line after $24 \mathrm{~h}$ of incubation with Vibrio sp. RE22. (a) Control hemocytes that are predominantly spread on the culture well surface; (b) hemocytes treated with $150 \mu \mathrm{g} \mathrm{ml} \mathrm{m}^{-1}$ bacterial ECPs showing phase-contract refringence due to rounding up (arrow). Scale bars $=10 \mu \mathrm{m}$

\section{DISCUSSION}

Experimental challenges with bacterial pathogens have been successfully used to evaluate host-pathogen interactions in oysters (e.g. Labreuche et al. 2006). In this work, we have successfully applied a modification of the experimental challenge protocol developed by Estes et al. (2004) in Pacific oysters Crassostrea gigas to test for differences in susceptibility to bacterial challenge between different lines of eastern oysters C. virginica. Factors affecting levels of resistance to bacterial challenge in oysters included temperature, bacterial isolate, age/size of the oyster, and oyster line. These experimental challenges will provide a useful 
model for studying host-pathogen interactions and mechanisms of resistance to bacterial infection in oysters.

We first provide evidence that 2 Vibrio spp. strains isolated from diseased Crassostrea gigas larvae (Estes et al. 2004) were able to induce mortalities in C. virginica larvae and juveniles. Consistent with observations in C. gigas, Vibrio sp. RE22 was more pathogenic to C. virginica larvae than Vibrio sp. RE101. The fact that Vibrio species isolated from C. gigas are able to induce mortalities in $C$. virginica is not surprising since this bacterial genus has been implicated in larval mortalities of different bivalve species in hatcheries (Paillard et al. 2004). The histological lesions observed after experimental challenge of $C$. virginica larvae and juveniles with Vibrio spp. RE22 and RE101 resembled those previously described for larval vibriosis in oysters (Tubiash et al. 1965, Elston et al. 1980, Estes et al. 2004), clams (Gomez-Leon et al. 2005), and cockles (Fujiwara et al. 1993), suggesting common mechanisms of Vibrio spp. pathogenesis in bivalve species.

Furthermore, we provide further evidence that Roseovarius crassostreae is the causative agent of JOD, now called Roseovarius oyster disease (Maloy et al. 2007). This disease was first observed in Crassostrea virginica in the northeastern USA in the late 1980s. Several causative agents have been evaluated since then, including bacteria of various genera, including Vibrio spp. (Lee et al. 1996, Paillard et al. 1996), Aeromonas and Pseudomonas spp. (Paillard et al. 1996), as well as protozoan parasites (Boettcher et al. 2006). Recently, a novel species of alphaproteobacterium, $R$. crassostreae, was identified as the etiological agent of ROD based on the observation that $R$. crassostreae is consistently the dominant bacterial species associated with JOD-affected animals (Boettcher et al. 1999, 2000, 2005) and the successful reproduction of disease signs after challenge of oyster juveniles by injection of $R$. crassostreae into the pallial cavity (Maloy et al. 2007). We have been able to cause mortalities in oyster larvae and juveniles by bath exposure to $R$. crassostreae, and have reproduced the characteristic signs of ROD in oyster juveniles between 15 and $22 \mathrm{~mm}$ in shell height. Those clinical signs included mantle lesions characterized by degeneration, erosion and the presence of dense spherical bodies termed 'coccoid bodies', and the presence of conchiolin deposits in the interior valve margins (Bricelj et al. 1992, Ford \& Borrero 2001). Consistent with recently published research in ROD-affected oysters (Boardman et al. 2008), the presence of $R$. crassostreae in experimentally challenged juveniles was restricted to the outer edge of the mantle and the conchiolin. Similarly, in brown ring disease, a bacterial pathology first described in the clam Ruditapes philippinarum, the etiological agent Vibrio tapetis can not be detected histologically within clam tissues (Paillard et al. 1994, Paillard \& Maes 1995).

Our results also confirm the important role of temperature on the pathogenesis of bacterial infection in oyster larvae and juveniles; temperatures at or above $25^{\circ} \mathrm{C}$ were necessary for Roseovarius crassostreae to cause significant mortalities among juvenile oysters. Furthermore, higher temperatures (25 versus $20^{\circ} \mathrm{C}$ ) also resulted in significantly higher mortalities when larvae were challenged with Vibrio spp. isolates RE22 and RE101. These results are in agreement with observations in oyster hatcheries that indicate higher incidence of bacillary necrosis at warmer temperatures (Ford \& Borrero 2001), and observations in the field that show that ROD mortalities occur when water temperatures increase (Bricelj et al. 1992). Warmer temperatures could result in higher mortalities by favoring bacterial proliferation and secretion of extracellular virulence factors. As observed in previous research (Ford \& Borrero 2001), warm temperatures were unlikely to be the direct cause of ROD, as holding the control oyster at $25^{\circ} \mathrm{C}$ did not caused unusual mortalities or conchiolin deposits on the interior of the valves.

Our results are also consistent with observations in the field that show that resistance to bacterial infection significantly increases with oyster age and size (Bricelj et al. 1992, Ford \& Borrero 2001). The capacity for repair as well as immune defenses including external barriers such as the shell may be more efficient at protecting the oyster from bacteria invasion as the oyster increases in size (Mount et al. 2004).

We demonstrate here that experimental challenges are particularly useful in evaluating differences in survival to bacterial challenge between oyster lines selectively breed for resistance to diseases caused by bacterial (ROD) or protistan (dermo and MSX) pathogens. In general, the MSX and dermo disease-resistant oyster line NEHY showed the highest levels of resistance to bacterial challenge of the 3 lines that we tested. Interestingly, NEHY oysters were more resistant to Roseovarius crassostreae challenge than oysters from FLOWERS at the larval and early juvenile stages (4-9 mm shell height). This is consistent with observations in the field that indicate that hybrids between NEHY and FLOWERS lines were more susceptible to ROD than the NEHY line (Guo et al. 2003). Although the FLOWERS line was not evaluated in this field trial, the field results are in agreement with our laboratory observations that the NEHY line is more resistant to ROD than the FLOWERS line. These observations suggest that the FLOWERS line may have lost resistance to ROD, possibly due to decreased disease pressure, or that resistance to ROD is dependent on the strain of $R$. crassostreae to which oysters are exposed. The find- 
ing that the NEHY line is relatively ROD-resistant is interesting as NEHY oysters have probably never been exposed to ROD, although it is often exposed to Vibrio spp. infections in the hatchery (X. Guo pers. comm.). These findings suggest that oysters may use common mechanisms of resistance to defend themselves against infection by different bacterial pathogens.

As a first step in the elucidation of the potential mechanisms of bacterial pathogenesis in oysters, we evaluated the effect of bacterial challenge and exposure to bacterial ECPs on the survival of oyster hemocytes from the 3 oyster lines. Hemocytes are major effectors of the immune system in oysters, and are also involved in other functions like digestion and wound healing (Bachere et al. 2004). Bacterial interactions with hemocytes are inevitable during invasive infections or when bacteria are ingested during the normal filtration and feeding processes. The virulence of Vibrio spp. and their capacity to induce mortalities during larval and juvenile stages has been correlated with their ability to produce extracellular toxins (Elston et al. 1980, Nottage \& Birkbeck 1987, Riquelme et al. 1996, Lambert et al. 2001, Gomez-Leon et al. 2005) that in some cases have ciliostatic activity, and are able to invade the bivalve tissues directly, causing necrosis (Nottage et al. 1989). The role of extracellular toxins in the pathogenicity of other bacterial genera (such as Roseovarius crassostreae) has been poorly studied. In the present work, we show for the first time that the ECPs of R. crassostreae (CV919-312 ${ }^{\mathrm{T}}$ ) can contribute to the development of the ROD pathogenesis since they have cytotoxic activity that can significantly diminish oyster hemocytes survival. It is also possible that the presence of a possible toxin with ciliostatic activity could have a detrimental action in the infected oysters, since feeding impairment has been observed in experimentally infected animals (Boettcher et al. 2000), consistent with the 'starved' appearance of naturally infected animals. The results obtained in the present work indicate that the ECPs of both Vibrio sp. RE22 and $R$. crassostreae CV919-312 ${ }^{\mathrm{T}}$ are heat-labile, suggesting that toxicity is not solely due to the lipopolysaccharide content of the ECPs (Gomez-Leon et al. 2005). The fact that no major differences in hemocyte survival after treatment with bacteria or ECPs (or at least not consistent with differences in oyster survival to bacterial challenge) were observed between the different oyster lines suggests that the differences in survival between these oysters are due to factors other than the toxic effects of bacteria on oyster hemocytes. Furthermore, the fact that these pathogenic bacteria are toxic to hemocytes from adult oysters suggests that external and mucosal barriers to infection are major contributors to the higher resistance to bacterial challenge observed in oysters as they age.
In summary, the use of in vivo experimental challenges by bath, which do not bypass mechanical barriers to infection, combined with in vivo challenges by injection and in vitro challenges of hemocytes will be useful in the elucidation of mechanisms of pathogenesis as well as the study of the mechanisms of resistance to bacterial challenge. Furthermore, future comparison of the results from the experimental challenges with the overall performance of the different oyster lines in the field would indicate the potential of using experimental challenges as a tool in the development of selectively-bred lines of oysters resistant to bacterial pathogens.

Acknowledgements. The authors thank K. Boettcher, R. Elston, and G. DeBrosse for providing bacterial strains, antibodies, and oysters, and X. Guo and K. Boettcher for helpful discussions. We thank K. Tammi at the RWU hatchery and H. Giddings at URI for support in the maintenance of the oysters. This research was supported by grants RIAI03-001 from the Rhode Island Aquaculture Initiative and 2002-34438-12688 from the US Department of Agriculture. R.H.S. was supported by a Coastal Fellowship for Undergraduate Research. This research was also made possible in part by use of the Rhode Island Genomics and Sequencing Center, supported by the NSF under EPSCoR Grant No. 0554548, and the RI-INBRE Research Core Facility supported by Grant No. P20 RR16457 from NCRR, NIH.

\section{LITERATURE CITED}

Abbe GR, Albright BW (2003) An improvement to the determination of meat condition index for the eastern oyster Crassostrea virginica (Gmelin 1791). J Shellfish Res 22: 747-752

Bachere E, Gueguen Y, Gonzalez M, de Lorgeril J, Garnier J, Romestand B (2004) Insights into the anti-microbial defense of marine invertebrates: the penaeid shrimps and the oyster Crassostrea gigas. Immunol Rev 198:149-168

Barber BJ, Davis CV, Crosby MA (1998) Cultured oysters, Crassostrea virginica, genetically selected for fast growth in the Damariscotta River, Maine, are resistant to mortality caused by juvenile oyster disease (JOD). J Shellfish Res $17: 1171-1175$

Boardman C (2005) Host-pathogen interactions between eastern oysters (Crassostrea virginica) and the bacterial agent of juvenile oyster disease (Roseovarius crassostreae). MS thesis, University of Maine

Boardman CL, Maloy AP, Boettcher KJ (2008) Localization of the bacterial agent of juvenile oyster disease (Roseovarius crassostreae) within affected eastern oysters (Crassostrea virginica). J Invertebr Pathol 97:

Boettcher KJ, Barber BJ, Singer JT (1999) Use of antibacterial agents to elucidate the etiology of juvenile oyster disease (JOD) in Crassostrea virginica and numerical dominance of an alpha-proteobacterium in JOD-affected animals. Appl Environ Microbiol 65:2534-2539

Boettcher KJ, Barber BJ, Singer JT (2000) Additional evidence that juvenile oyster disease is caused by a member of the Roseobacter group and colonization of nonaffected animals by Stappia stellulata-like strains. Appl Environ Microbiol 66:3924-3930 
Boettcher KJ, Geaghan KK, Maloy AP, Barber BJ (2005) Roseovarius crassostreae sp. nov., a member of the Roseobacter clade and the apparent cause of juvenile oyster disease (JOD) in cultured Eastern oysters. Int J Syst Evol Microbiol 55:1531-1537

Boettcher KJ, Smolowitz R, Lewis EJ, Allam B and others (2006) Juvenile oyster disease (JOD) in Crassostrea virginica: synthesis of knowledge and recommendations. J Shellfish Res 25:683-686

Bricelj VM, Ford SE, Borrero FJ, Perkins FO and others (1992) Unexplained mortalities of hatchery-reared, juvenile oysters Crassostrea virginica (Gmelin). J Shellfish Res 11:331-347

Brown C (1981) A study of two shell-fish-pathogenic Vibrio strains isolated from a Long Island hatchery during a recent outbreak of disease. J Shellfish Res 1:83-87

Brown C, Tettelbach LP (1988) Characterization of a nonmotile Vibrio sp. pathogenic to larvae of Mercenaria mercenaria and Crassostrea virginica. Aquaculture 74: 195-204

Castagna M, Gibbons MC, Kurkowski K (1996) Culture: applications. In: Kennedy VS, Newell RI (eds) The eastern oyster, Crassostrea virginica. Maryland Sea Grant College, College Park, MD, p 675-690

Davis CV, Barber BJ (1994) Size-dependent mortality in hatchery-reared populations of oysters, Crassostrea virginica, Gmelin 1791, affected by juvenile oyster disease. J Shellfish Res 13:137-142

Davis CV, Barber BJ (1999) Growth and survival of selected lines of eastern oysters, Crassostrea virginica (Gmelin 1791) affected by juvenile oyster disease. Aquaculture 178:253-271

Elston R, Leibovitz L, Laurent PJ (1980) Pathogenesis of experimental vibriosis in larval American oysters, Crassostrea virginica. Can J Fish Aquat Sci 37:964-978

Estes RM, Friedman CS, Elston RA, Herwig RP (2004) Pathogenicity testing of shellfish hatchery bacterial isolates on Pacific oyster Crassostrea gigas larvae. Dis Aquat Org 58:223-230

Ford SE, Borrero FJ (2001) Epizootiology and pathology of juvenile oyster disease in the eastern oyster, Crassostrea virginica. J Invertebr Pathol 78:141-154

Ford SE, Tripp MR (1996) Diseases and defense mechanisms. In: Kennedy VS, Newell RI, Eble AE (eds) The eastern oyster, Crassostrea virginica. Maryland Sea Grant, College Park, MD, p 581-660

Fujiwara M, Ueno Y, Iwao A (1993) A Vibrio sp. associated with mortalities in cockle larvae Fulvia mutica (Mollusca: Cardidae). Fish Pathol 28:83-89

- Gomez-Leon J, Villamil L, Lemos ML, Novoa B, Figueras A (2005) Isolation of Vibrio alginolyticus and Vibrio splendidus from aquacultured carpet shell clam (Ruditapes decussatus) larvae associated with mass mortalities. Appl Environ Microbiol 71:98-104

Guo X, Ford SE, DeBrosse G, Smolowitz R (2003) Breeding and evaluation of eastern oyster strains selected for MSX, dermo and JOD resistance. J Shellfish Res 22:333-334

Labreuche Y, Lambert C, Soudant P, Boulo V, Huvet A, Nicolas JL (2006) Cellular and molecular hemocyte responses of the Pacific oyster, Crassostrea gigas, following bacterial infection with Vibrio aestuarianus strain 01/32. Microbes Infect 8:2715-2724

Editorial responsibility: Eugene Burreson, Gloucester Point, Virginia, USA
Lambert C, Nicolas J, Bultel V (2001) Toxicity to bivalve hemocytes of pathogenic Vibrio cytoplasmic extract. J Invertebr Pathol 77:165-172

Lee M, Taylor GT, Bricelj VM, Ford SE, Zahn S (1996) Evaluation of Vibrio spp. and microplankton blooms as causative agents of juvenile oyster disease in Crassostrea virginica (Gmelin). J Shellfish Res 15:319-329

Lewis EJ (2001) Juvenile oyster disease (JOD) and management strategies: a review. Bull Natl Res Inst Aquac (Suppl 5):101-109

Liu PV (1957) Survey of hemolysin production among species of pseudomonads. J Bacteriol 74:718-727

Maloy AP, Ford SE, Karney RC, Boettcher KJ (2007) Roseovarius crassostreae, the etiological agent of juvenile oyster disease (now to be known as Roseovarius oyster disease) in Crassostrea virginica. Aquaculture 269:71-83

Mount AS, Wheeler AP, Paradkar RP, Snider D (2004) Hemocyte-mediated shell mineralization in the eastern oyster. Science 304:297-300

- Nottage AS, Birkbeck TH (1987) Production of proteinase during experimental infection of Ostrea edulis L. larvae with Vibrio alginolyticus NCMB 1339 and the antigenic relationship between proteinases produced by marine vibrios pathogenic for fish and shellfish. J Fish Dis 10:265-273

Nottage AS, Sinclair PD, Birkbeck TH (1989) Role of lowmolecular-weight ciliostatic toxins in vibriosis of bivalve mollusks. J Aquat Anim Health 1:180-186

Paillard C, Maes P (1995) The brown ring disease in the Manila clam, Ruditapes philippinarum: I. Ultrastructural alterations of the periostracal lamina. J Invertebr Pathol 65:91-100

Paillard C, Maes P, Oubella R (1994) Brown ring disease in clams. Annu Rev Fish Dis 4:219-240

Paillard C, Ashton-Alcox K, Ford SE (1996) Changes in bacterial densities and hemocyte parameters in eastern oysters, Crassostrea virginica, affected by juvenile oyster disease. Aquat Living Resour 9:145-158

Paillard C, Le Roux F, Borreg JJ (2004) Bacterial disease in marine bivalves, a review of recent studies: trends and evolution. Aquat Living Resour 17:477-498

Ragone Calvo LM, Calvo GW, Burreson EM (2003) Dual disease resistance in a selectively bred eastern oyster, Crassostrea virginica, strain tested in Chesapeake Bay. Aquaculture 220:69-87

Renault T, Chollet B, Cochennec N, Gerard A (2002) Shell disease in eastern oysters, Crassostrea virginica, reared in France. J Invertebr Pathol 79:1-6

Riquelme C, Toranzo AE, Barja JL, Vergara N, Araya R (1996) Association of Aeromonas hydrophila and Vibrio alginolyticus with larval mortalities of scallop (Argopecten purpuratus). J Invertebr Pathol 67:213-218

Roch P (1999) Defense mechanisms and disease prevention in farmed marine invertebrates. Aquaculture 172:125-145

Shaw BL, Battle HI (1957) The gross and microscopic anatomy of the digestive tract of Crassostrea virginica (Gmelin). Can J Zool 35:325-347

Tubiash HS, Chanley PE, Leifson E (1965) Bacillary necrosis, a disease of larval and juvenile bivalve mollusks. I. Etiology and epizootiology. J Bacteriol 90:1036-1044

Yu ZN, Guo XM (2006) Identification and mapping of diseaseresistance QTLs in the eastern oyster, Crassostrea virginica Gmelin. Aquaculture 254:160-170

Submitted: April 26, 2007; Accepted: January 31, 2008

Proofs received from author(s): March 14, 2008 